\title{
Perbedaan ukuran dan bentuk lengkung gigi antara laki-laki dan perempuan suku Bugis, Makassar, dan Toraja \\ Difference of size and shape of dental arch between male and female of Buginese, Makassarese, and Toraja
}

\author{
${ }^{1}$ Irene Edith Rieuwpassa, ${ }^{2}$ Syamsiar Toppo, ${ }^{3}$ Sri Dian Haerawati \\ ${ }^{1}$ Bagian Biologi Oral \\ ${ }^{2}$ Bagian Radiologi \\ ${ }^{3}$ Mahasiswa tahapan profesi \\ Fakultas Kedokteran Gigi Universitas Hasanuddin \\ Makassar, Indonesia
}

\begin{abstract}
Factors which influence the dental arch changes including genetic and environment. This study aims to determine the differences in size and shape of dental arch between men and women of Buginese, Makassarese and Torajanese. This study is an observational study, with a cross-sectional study design. The sampling method was purposive sampling, and number of samples were 90 samples obtained from 90 people with 30 people for each tribe, consist of 15 men and 15 women, aged 18-25 years, with full dentition. Data were obtained through tcasting models of the maxillary and mandibular samples then were measured by using a ruler and caliper, then calculated using formula to determine, register, and analyze the size and shape of dental arch. Using multiple statistics, including t-test, ANOVA, chi-square test, and marginal of homogenity test there are significant differences regarding the size and shape of dental arch between men and women of the Buginese, Makassarese, and Torajanese. There is only significant difference of maxillary dental arch for Buginese, Makassarese, and Torajanese.
\end{abstract}

Key words: dental arch, men, women, Buginese, Makassarese, Torajanese

\begin{abstract}
ABSTRAK
Faktor yang mempengaruhi perubahan lengkung gigi, antara lain faktor genetik dan lingkungan. Penelitian ini bertujuan untuk mengetahui perbedaan ukuran dan bentuk lengkung gigi antara laki-laki dan perempuan suku Bugis, Makassar, dan Toraja. Penelitian ini merupakan penelitian observasional, dengan desain studi cross-sectional. Metode pengambilan sampel yang digunakan adalah purposive sampling, yang besarnya adalah 90. Sampel terdiri dari 30 orang tiap suku, yang masing-masing terdiri atas 15 laki-laki dan 15 perempuan, yang berumur 18-25 tahun yang masih lengkap gigi-geliginya. Data diperoleh dengan mencetak rahang atas dan bawah sampel kemudian dilakukan pengukuran menggunakan penggaris dan caliper. Setelah itu dilakukan perhitungan dengan menggunakan rumus untuk menentukan ukuran dan bentuk lengkung gigi, dan dilakukan pencatatan serta dianalisis. Dari analisis tabel yang menggunakan beberapa uji statistik, diantaranya uji-t, Anova, uji chi-square, marginal of homogenity menunjukkan bahwa terdapat perbedaan yang signifikan mengenai ukuran dan bentuk lengkung gigi antara laki-laki dan perempuan suku Bugis, Makassar, dan Toraja. Akan tetapi pada bentuk lengkung gigi rahang bawah tidak terdapat perbedaan yang signifikan, hanya pada bentuk lengkung gigi rahang atas yang terdapat perbedaan yang signifikan pada suku Bugis, Makassar, dan Toraja.
\end{abstract}

Kata kunci: lengkung gigi, laki-laki, perempuan, suku Bugis, suku Makassar, suku Toraja

Koresponden: Irene E. Rieuwpassa, Bagian Biologi Oral Fakultas Kedokteran Gigi Universitas Hasanuddin, J1. Perintis Kemerdekaan Km.10, Makassar 90245. E-mail:drgirene@yahoo.com

\section{PENDAHULUAN}

Sebagian besar penduduk Indonesia termasuk ras Paleomongoloid yang disebut dengan ras Melayu. Ras Melayu terdiri dari kelompok ProtoMelayu (Melayu tua) dan Deutro-Melayu (Melayu muda). Ciri fisik kedua kelompok ras ini berbeda dilihat dari bentuk kepala,yaitu dolicocephalis pada Proto-Melayu dan brachycephalis pada DeutroMelayu. Bentuk dan ukuran rahang pada kedua ras ini juga berbeda karena dipengaruhi ras dan bentuk kepala yang berbeda.

Pada dasarnya ukuran dan bentuk lengkung gigi geligi ditentukan oleh skeleton cartilaginous dari maksila dan mandibula pada masa janin, kemudian berkembang mengikuti benih gigi dan tulang rahang yang tumbuh. Selama periode pasca natal, kekuatan lingkungan yang bekerja pada mahkota gigi mempengaruhi ukuran dan bentuk lengkung gigi. ${ }^{1}$

Perubahan lengkung gigi pada masa tumbuh kembang, sangat dipengaruhi oleh tumbuh kembang dari prosesus alveolaris. Secara umum lengkung gigi berkembang pada tahap gigi bercampur lalu cenderung stabil sampai tahap gigi 
tetap. Pada mandibula, tumbuh kembang lengkung gigi berlangsung dari usia 4-8 tahun. Sedangkan pada maksila hal ini berlangsung dari usia 4-13 tahun dan cenderung lebih stabil hingga dewasa. ${ }^{2}$

Salah satu organ yang berperan penting dalam menunjang metabolisme tubuh adalah gigi. Gigi yang tersusun pada tulang rahang membentuk struktur lengkung yang berbeda secara alami, dari segi ukuran maupun bentuk yang dipengaruhi oleh bentuk tulang penyokong lengkung gigi, erupsi, dan kerusakan pada gigi. ${ }^{3}$

Garis yang menghubungkan titik kontak antar gigi satu dengan gigi yang lain disebut sebagai lengkung gigi. Lengkung gigi didukung oleh setiap gigi yang terletak di dalam suatu basis tulang. Bentuk lengkung berdasarkan bagian anterior kurva dikategorikan menjadi tiga, yaitu ovoid, tapered, dan square. Ketiga bentuk lengkung memiliki kemiripan yang cukup tinggi sehingga sulit untuk dibedakan. $^{3}$

Memperhatikan makna lengkung gigi dalam kehidupan sehari-hari, penelitian ini bertujuan untuk mengetahui perbedaan ukuran dan bentuk lengkung gigi antara laki-laki dan perempuan suku Bugis, Makassar, dan Toraja

\section{BAHAN DAN METODE}

Penelitian observasional deskriptif analitik dengan desain studi cross-sectional ini bertujuan untuk mengumpulkan data tentang ukuran dan bentuk lengkung gigi. Penelitian ini dilakukan di Kota Makassar, Kabupaten Maros dan Toraja. Sampel penelitian ini diperoleh dari populasi masyarakat suku Bugis, Makassar, dan Toraja dengan dua generasi keturunan pada suku yang sama, berusia 18-25 tahun dan berjenis kelamin laki-laki dan perempuan, serta belum kehilangan satupun giginya.

Dengan metode purposive sampling, diperoleh jumlah sampel pada penelitian ini adalah 90 sampel yang terdiri dari 30 orang tiap suku, yang masing- masing terdiri dari 15 laki-laki dan 15 perempuan. Jumlah ini memenuhi syarat tercapainya distribusi normal.

Sampel adalah masyarakat laki-laki dan perempuan suku Bugis, Makassar, dan Toraja yang bertempat tinggal di Kota Makassar, Kabupaten Maros dan Toraja yang telah lulus seleksi. Mereka diinstruksikan untuk duduk dalam keadaan rileks dengan posisi rahang bawah sejajar dengan lantai. Sendok cetak dicobakan ke subjek dan dipilih sendok cetak yang sesuai dengan lengkung rahang atas dan bawah subjek.

Dengan menggunakan rubber bowl dan spatel, dilakukan pencampuran bahan cetak alginat dan air dengan perbandingan powder dan liquid sesuai dengan petunjuk pabrik. Adonan bahan cetak diisi ke dalam sendok cetak rahang atas dan rahang bawah, lalu dimasukkan ke dalam mulut untuk mendapat cetakan rahang atas dan rahang bawah subjek. Hasil cetakan segera diisi dengan gips keras yang telah diaduk dengan perbandingan air dan gips 1:5,seperti petunjuk penggunaan bahan, hingga homogen, kemudian ditunggu sampai adonan gips mengeras. Model dikeluarkan dari cetakan, diberi label,hingga diperoleh model positif, dan dilakukan pengukuran dengan menggunakan penggaris dan caliper. Data yang diperoleh dicatat, lalu diolah, dideskripsikan dan dianalisis.

Data kemudian dianalisis secara statistik dengan menggunakan uji-t, uji Anova, uji chisquare, dan uji marginal of homogenity.

\section{HASIL}

Tabel 1 memperlihatkan nilai rata-rata jarak interpremolar, intermolar, dan panjang lengkung gigi laki-laki lebih besar daripada perempuan. Nilai rata-rata interpremolar, intermolar, dan panjang lengkung gigi laki-laki berturut-turut adalah 35,25 $\mathrm{mm}, 44,06 \mathrm{~mm}$, dan 17,62 $\mathrm{mm}$; sedangkan nilai rata-rata interpremolar, intermolar, dan panjang lengkung gigi perempuan berturut-turut adalah

Tabel 1 Perbedaan ukuran lengkung gigi berdasarkan jenis kelamin dan suku

\begin{tabular}{|c|c|c|c|c|c|c|}
\hline \multirow{3}{*}{ Variabel } & \multicolumn{6}{|c|}{ Ukuran Lengkung Gigi } \\
\hline & \multicolumn{2}{|c|}{ Interpremolar } & \multicolumn{2}{|c|}{ Intermolar } & \multicolumn{2}{|c|}{ Panjang lengkung gigi } \\
\hline & Mean $\pm S D$ & $p$-value & Mean $\pm S D$ & $p$-value & Mean $\pm S D$ & $p$-value \\
\hline Jenis Kelamin & & \multirow{4}{*}{$0,045^{*}$} & & \multirow{4}{*}{$0,035^{*}$} & & \multirow{4}{*}{$0,05 *$} \\
\hline Laki-laki & $35,25 \pm 2,55$ & & $44,06 \pm 3,18$ & & $17,62 \pm 1,27$ & \\
\hline Perempuan & $34,30 \pm 2,02$ & & $42,88 \pm 2,52$ & & $17,15 \pm 1,01$ & \\
\hline Suku & & & & & & \\
\hline Bugis & $34,29 \pm 2,31$ & \multirow{3}{*}{$0,046 * *$} & $42,86 \pm 2,89$ & \multirow{3}{*}{$0,032 * *$} & $17,14 \pm 1,15$ & \multirow{3}{*}{$0,036 * *$} \\
\hline Makassar & $34,37 \pm 2,01$ & & $42,96 \pm 2,52$ & & $17,18 \pm 1,00$ & \\
\hline Toraja & $35,66 \pm 2,47$ & & $44,58 \pm 3,09$ & & $17,83 \pm 1,23$ & \\
\hline Total & $34,77 \pm 2,33$ & & $43,47 \pm 2,92$ & & $17,38 \pm 1,16$ & \\
\hline
\end{tabular}


Tabel 2 Perbedaan ukuran lengkung gigi antara jenis kelamin berdasarkan suku

\begin{tabular}{|c|c|c|c|c|c|c|c|}
\hline \multirow{3}{*}{ Suku } & \multirow{3}{*}{$\begin{array}{c}\text { Jenis } \\
\text { Kelamin }\end{array}$} & \multicolumn{6}{|c|}{ Ukuran Lengkung Gigi } \\
\hline & & \multicolumn{2}{|c|}{ Interpremolar } & \multicolumn{2}{|c|}{ Intermolar } & \multicolumn{2}{|c|}{ Panjang lengkung gigi } \\
\hline & & Mean $\pm S D$ & p-value & Mean $\pm S D$ & p-value & Mean $\pm S D$ & $p$-value \\
\hline \multirow{2}{*}{ Bugis } & Laki-laki & $35,00 \pm 2,40$ & \multirow{2}{*}{$0,034^{*}$} & $43,75 \pm 3,01$ & \multirow{2}{*}{$0,033^{*}$} & $17,50 \pm 1,20$ & \multirow{2}{*}{$0,094 * *$} \\
\hline & Perempuan & $33,58 \pm 2,05$ & & $41,97 \pm 2,56$ & & $16,79 \pm 1,02$ & \\
\hline \multirow{2}{*}{ Makassar } & Laki-laki & $34,75 \pm 2,17$ & \multirow{2}{*}{$0,302 * *$} & $43,43 \pm 2,71$ & \multirow{2}{*}{$0,042 *$} & $17,37 \pm 1,08$ & \multirow{2}{*}{$0,232 * *$} \\
\hline & Perempuan & $34,00 \pm 1,84$ & & $42,50 \pm 2,30$ & & $17,00 \pm 0,92$ & \\
\hline \multirow{2}{*}{ Toraja } & Laki-laki & $36,00 \pm 2,99$ & \multirow{2}{*}{$0,470 * *$} & $45,00 \pm 3,74$ & \multirow{2}{*}{$0,477 * *$} & $18,00 \pm 1,49$ & \multirow{2}{*}{$0,488 * *$} \\
\hline & Perempuan & $35,33 \pm 1,85$ & & $44,16 \pm 2,32$ & & $17,66 \pm 0,92$ & \\
\hline
\end{tabular}

*Independent sample t-test: $p \circlearrowleft 0.05$; significant

**Independent sample t-test: $p>0.05$; not significant

Tabel 3 Perbedaan proporsi bentuk lengkung gigi rahang atas berdasarkan jenis kelamin dan suku

\begin{tabular}{|c|c|c|c|c|c|}
\hline \multirow{2}{*}{ Jenis kelamin dan Suku } & \multicolumn{3}{|c|}{ Bentuk Lengkung Rahang Atas } & \multirow{2}{*}{ Total } & \multirow{2}{*}{$p$-value } \\
\hline & Square & Oval & Tapered & & \\
\hline \multicolumn{6}{|l|}{ Jenis Kelamin } \\
\hline Laki-laki & $32(45,7 \%)$ & $11(61,1 \%)$ & $2(100 \%)$ & $45(50,0 \%)$ & \multirow{2}{*}{$0,018^{*}$} \\
\hline Perempuan & $38(54,3 \%)$ & $7(38,9 \%)$ & $0(0,0 \%)$ & $45(50,0 \%)$ & \\
\hline \multicolumn{6}{|l|}{ Suku } \\
\hline Bugis & $23(32,9 \%)$ & $5(27,8 \%)$ & $2(100 \%)$ & $30(33,3 \%)$ & \multirow{3}{*}{$0,035^{*}$} \\
\hline Makassar & $24(34,3 \%)$ & $6(33,3 \%)$ & $0(0,0 \%)$ & $30(33,3 \%)$ & \\
\hline Toraja & $23(32,9 \%)$ & $7(38,9 \%)$ & $0(0,0 \%)$ & $30(33,3 \%)$ & \\
\hline Total & $70(77,8 \%)$ & $18(20,0 \%)$ & $2(2,2 \%)$ & $90(100 \%)$ & \\
\hline
\end{tabular}

*Chi-square test: $p \unlhd$.05; significant

$34,30 \mathrm{~mm}, 42,88 \mathrm{~mm}$, dan 17,15 mm. Dengan uji-t independent sample, ditunjukkan bahwa terdapat perbedaan ukuran interpremolar, intermolar, dan panjang lengkung gigi yang signifikan antara lakilaki dan perempuan. Selain itu juga terlihat bahwa ternyata suku Toraja memiliki lebar interpremolar, intermolar, dan panjang lengkung gigi yang paling besar, tetapi sebaliknya suku Bugis memiliki lebar interpremolar, intermolar, dan panjang lengkung gigi yang paling kecil. Suku Toraja memiliki ratarata 35,66 mm lebar interpremolar, 44,58 $\mathrm{mm}$ lebar intermolar, dan $17,83 \mathrm{~mm}$ panjang lengkung gigi. Hasil uji statistik ANOVA menunjukkan perbedaan ukuran lebar interpremolar, intermolar, dan panjang lengkung gigi yang signifikan antara suku Bugis, suku Makassar, dan suku Toraja.

Tabel 2 menunjukkan distribusi ukuran ratarata lebar interpremolar, intermolar, dan panjang lengkung gigi subjek berjenis kelamin laki-laki dan perempuan berdasarkan suku. Hasil penelitian menunjukkan laki-laki dari ketiga suku tersebut memiliki ukuran lebar interpremolar, intermolar, dan panjang lengkung gigi yang lebih besar daripada perempuan. Secara keseluruhan, laki-laki suku Toraja memiliki lebar rata-rata interpremolar, intermolar, dan panjang lengkung gigi yang paling tinggi daripada laki-laki maupun perempuan dari suku yang lain.

Pada tabel 3 tampak bahwa jumlah perempuan yang memiliki bentuk lengkung gigi rahang atas square lebih banyak daripada laki-laki, yaitu 38 perempuan $(54,3 \%)$ dan 32 laki-laki (45,7\%). Selanjutnya, bentuk lengkung gigi rahang atas oval dan tapered lebih banyak dimiliki oleh sampel lakilaki. Hasil uji chi-square yang digunakan untuk membedakan proporsi bentuk lengkung gigi rahang atas antara laki-laki dan perempuan,antara dan suku Bugis, Makassar, dan Toraja. Dari aspek suku, terlihat sampel suku Makassar memiliki jumlah terbanyak, yaitu 24 orang $(34,3 \%)$ dengan bentuk lengkung gigi rahang atas square. Adapun, suku Bugis memiliki bentuk lengkung gigi tapered yang paling banyak dibandingkan suku lainnya.

Tabel 4 memperlihatkan hal yang berbanding terbalik dengan tabel 5, yaitu laki-laki memiliki bentuk lengkung gigi square yang lebih banyak daripada perempuan dengan jumlah $45(51,7 \%)$ dibanding 42 (48,3\%). Meskipun demikian, bentuk lengkung gigi tapered juga ditemukan pada perempuan.Hasil uji statistik menunjukkan terdapat perbedaan proporsi yang signifikan tentang bentuk lengkung gigi rahang bawah antara laki-laki dan perempuan. Berdasarkan suku, Makassar memiliki bentuk lengkung gigi rahang bawah square yang paling banyak,yaitu 30 orang (34,5\%). Adapun, suku Toraja memiliki bentuk lengkung gigi rahang bawah yang tapered paling banyak. Akan tetapi, hasil uji menunjukkan tidak terdapat perbedaan proporsi bentuk lengkung gigi rahang bawah yang signifikan antara suku Bugis, Makassar, dan Toraja. 
Tabel 4 Perbedaan proporsi bentuk lengkung gigi rahang bawah berdasarkan jenis kelamin dan suku

\begin{tabular}{|c|c|c|c|c|c|}
\hline \multirow{2}{*}{ Jenis kelamin dan Suku } & \multicolumn{3}{|c|}{ Bentuk Lengkung Rahang Bawah } & \multirow{2}{*}{ Total } & \multirow[b]{2}{*}{$p$-value } \\
\hline & Square & Oval & Tapered & & \\
\hline \multicolumn{6}{|l|}{ Jenis Kelamin } \\
\hline Laki-laki & $45(51,7 \%)$ & $0(0,0 \%)$ & $0(0,0 \%)$ & $45(50,0 \%)$ & \multirow{3}{*}{$0,021 *$} \\
\hline Perempuan & $42(48,3 \%)$ & $2(100 \%)$ & $1(100 \%)$ & $45(50,0 \%)$ & \\
\hline \multicolumn{5}{|l|}{ Suku } & \\
\hline Bugis & $29(33,3 \%)$ & $1(50,0 \%)$ & $0(0,0 \%)$ & $30(33,3 \%)$ & \multirow{3}{*}{$0,054 * *$} \\
\hline Makassar & $30(34,5 \%)$ & $0(0,0 \%)$ & $0(0,0 \%)$ & $30(33,3 \%)$ & \\
\hline Toraja & $28(32,2 \%)$ & $1(50,0 \%)$ & $3(3,3 \%)$ & $30(33,3 \%)$ & \\
\hline Total & $87(96,7 \%)$ & $2(2,2 \%)$ & $1(1,1 \%)$ & $90(100,0 \%)$ & \\
\hline
\end{tabular}

Tabel 5 Perbedaan proporsi bentuk lengkung gigi rahang atas dan rahang bawah

\begin{tabular}{|c|c|c|c|c|c|}
\hline \multirow{2}{*}{ Bentuk lengkung rahang atas } & \multicolumn{3}{|c|}{ Bentuk Lengkung Rahang Bawah } & \multirow{2}{*}{ Total } & \multirow{2}{*}{ p-value } \\
\hline & Square & Oval & Tapered & & \\
\hline \multicolumn{6}{|l|}{ Bentuk lengkung } \\
\hline Square & $67(77,0 \%)$ & $2(100 \%)$ & $1(100 \%)$ & $70(77,8 \%)$ & \\
\hline Oval & $18(20,7 \%)$ & $0(0,0 \%)$ & $0(0,0 \%)$ & $18(20,0 \%)$ & $0,001 *$ \\
\hline Tapered & $2(2,3 \%)$ & $0(0,0 \%)$ & $0(0,0 \%)$ & $2(2,2 \%)$ & \\
\hline Total & $87(96,7 \%)$ & $2(2,2 \%)$ & $1(1,1 \%)$ & $90(100 \%)$ & \\
\hline
\end{tabular}

Pada tabel 5 ditunjukkan perbedaan proporsi bentuk lengkung gigi rahang atas dan bawah. Dari tabel ini terlihat bahwa sampel yang memiliki bentuk lengkung gigi rahang atas dan bawah yang square adalah yang paling banyak dibandingkan bentuk yang lain. Adapun, bentuk lengkung gigi tapered merupakan bentuk lengkung gigi yang paling sedikit dimiliki oleh sampel. Walaupun demikian, bentuk lengkung gigi oval hanya berbeda satu orang dengan bentuk tapered.

\section{PEMBAHASAN}

Dari hasil penelitian mengenai ukuran lengkung gigi laki-laki dan perempuan seperti yang terlihat pada Tabel 1 , nilai rata-rata interpremolar, intermolar, dan panjang lengkung gigi laki-laki berturut-turut adalah $35,25 \mathrm{~mm}, 44,06 \mathrm{~mm}$, dan $17,62 \mathrm{~mm}$; sedangkan nilai rata-rata interpremolar, intermolar, dan panjang lengkung gigi perempuan berturut-turut adalah $34,30 \mathrm{~mm}, 42,88 \mathrm{~mm}$, dan $17,15 \mathrm{~mm}$. Rata-rata nilai lebar interpremolar, intermolar, dan panjang lengkung gigi laki-laki lebih besar daripada perempuan.

Dilaporkan penelitian pada mahasiswa laki-laki dan perempuan suku Jawa di Fakultas Kedokteran Gigi Universitas Gadjah Mada angkatan tahun 20062009. Pada laki-laki mempunyai nilai rata-rata 39,05 mm interpremolar, 48,99 mm intermolar, dan 19,67 mm panjang lengkung gigi, sedangkan pada perempuan nilai rata-rata $37,33 \mathrm{~mm}$ interpremolar, $46,89 \mathrm{~mm}$ intermolar, dan $18,89 \mathrm{~mm}$ panjang lengkung gigi.Hal tersebut sesuai dengan penelitian
Burris dan Harris yang dilakukan di Amerika, juga menjumpai bahwa rerata jarak interpremolar dan intermolar rahang atas laki-laki lebih besar daripada perempuan. Hasil penelitian ini juga mendukung hasil penelitian Huth dkk, dan Kunz dkk, yang menjumpai adanya perbedaan lebar intermolar yang signifikan antara laki-laki dan perempuan, demikian pula penelitian Agnihotri dan Gulati pada populasi Indian Utara,Ling dan Wong pada populasi Cina Selatan. ${ }^{1}$ Tampak bahwa rata-rata ukuran lengkung gigi-geligi laki-laki lebih besar daripada perempuan. Anak lelaki menunjukkan peningkatan pertumbuhan yang meningkat dalam hal lengkung geligi. Faktor yang mempengaruhi perkembangan pertumbuhan kompleks maksila yaitu abnormalnya pertumbuhan palatal,tekanan pada proses kelahiran, faktor genetik, dan faktor lingkungan. ${ }^{1}$

Rata-rata nilai interpremolar, intermolar, dan panjang lengkung gigi dari subjek suku Bugis, suku Makassar dan suku Toraja memiliki ukuran yang tidak jauh berbeda, walaupun suku Toraja memiliki ukuran lengkung gigi yang paling besar dan suku Bugis yang memiliki ukuran lengkung gigi yang paling kecil. Hal tersebut mungkin terjadi karena secara genetik, suku Toraja mempunyai ukuran rahang yang lebih besar dibandingkan suku Bugis, yang disebabkan oleh faktor lingkungan, yaitu jenis makanan. Umumnya bahan makanan suku Toraja memerlukan kekuatan kunyah yang lebih besar. Meskipun demikian, proses evolusi sejalan dengan perkembangan peradaban manusia sehingga ukuran rahang berkurang. Selain karena faktor lingkungan, 
kejadian ini juga disebabkan karena faktor turunan. Suku Toraja yang menikah dengan suku lain yang secara genetik memiliki rahang yang kecil. ${ }^{4}$

Pada Tabel 3 tergambarkan bahwa perempuan yang memiliki bentuk lengkung rahang atas square lebih banyak daripada laki-laki,yaitu 38 perempuan $(54,3 \%)$ dan 32 laki-laki $(45,7 \%)$. Adapun, bentuk lengkung rahang atas yang oval dan tapered lebih banyak dimiliki oleh sampel laki-laki. Pada tabel 4 terlihat hal yang berbanding terbalik dengan tabel 3 yaitu bahwa laki-laki memiliki bentuk lengkung gigi square yang lebih banyak daripada perempuan dengan jumlah 45 lelaki $(51,7 \%)$ dan 42 perempuan $(48,3 \%)$. Meskipun demikian, bentuk lengkung gigi tapered juga ditemukan pada perempuan.

Menurut bentuk lengkung gigi antara suku Bugis, Makassar, dan Toraja, terlihat bahwa suku Makassar memiliki jumlah sampel dengan bentuk lengkung rahang atas square yang paling banyak, yaitu 24 orang $(34,3 \%)$. Suku Bugis memiliki bentuk lengkung tapered yang paling banyak dibandingkan suku lainnya. Sesuai dengan tabel 3, suku Makassar memiliki bentuk lengkung gigi rahang bawah square yang paling banyak, yaitu 30 orang $(34,5 \%)$. Adapun, suku Toraja memiliki bentuk lengkung gigi rahang bawah yang tapered paling banyak. Hasil uji statistik pada tabel 4 menunjukkan tidak terdapat perbedaan proporsi bentuk lengkung gigi rahang bawah yang signifikan antara suku Bugis, suku Makassar,dan suku Toraja. Hasil yang tidak signifikan diperoleh karena bentuk lengkung gigi suku Toraja yang awalnya besar atau berbentuk tapered. Dari penelitian terdahulu diperoleh gambaran bahwa ukuran rahang yang besar yang merupakan ciri khas suku Toraja, saat ini tidak lagi menjadi ciri khas suku tersebut, karena masyarakat suku Toraja telah mengalami evolusi dari faktor lingkungannya,yaitu berubahnya kebiasaan makan makanan yang relatif lebih keras ke makanan yang relatif lebih lunak. Demikian juga yang terjadi pada suku Bugis. ${ }^{4}$ Jadi tidak seluruhnya suku Toraja memiliki lengkung gigi yang besar dan tidak semuanya berbentuk tapered; karena berbagai faktor.

Penelitian mengenai bentuk lengkung gigi juga pernah dilakukan oleh McLaughlin dengan hasil dari 200 kasus dengan subyek dari ras kaukasia $50 \%$ memiliki bentuk lengkung gigi tapered, $42 \%$ ovoid, dan $8 \%$ square. Kook melaporkan hasil penelitian dengan populasi orang Korea 46,7\% square, $34,5 \%$ ovoid dan $18,8 \%$ tapered. Nojima melaporkan penelitian pada 160 kasus pada pasien Jepang $45,6 \%$ square, $42,5 \%$ ovoid, dan $11,9 \%$ tapered. $^{2}$

Perbedaan proporsi bentuk lengkung gigi rahang atas dan rahang bawah, bentuk lengkung rahang atas dan rahang bawah yang square adalah yang paling banyak dibandingkan yang lain. Bentuk lengkung tapered merupakan bentuk lengkung yang paling sedikit dimiliki oleh sampel. Walaupun demikian, bentuk lengkung oval hanya berbeda satu orang dengan bentuk tapered.

Dari hasil penelitian tentang perbedaan ukuran dan bentuk lengkung gigi antara laki-laki dan perempuan suku Bugis, Makassar, dan Toraja disimpulkan bahwa ada perbedaan yang signifikan pada rata-rata ukuran interpremolar, intermolar dan panjang lengkung gigi laki-laki dan perempuan serta pada suku Bugis, Makassar, dan Toraja. Selain itu juga terdapat perbedaan yang signifikan pada bentuk lengkung gigi antara laki-laki dan perempuan, serta pada bentuk lengkung gigi rahang atas antara suku Bugis, Makassar dan Toraja, tetapi tidak ada perbedaan yang signifikan pada bentuk lengkung gigi rahang bawah antara suku Bugis, Makassar, dan Toraja. Selain itu terdapat perbedaan proporsi bentuk lengkung rahang atas dan rahang bawah yang signifikan.

\section{DAFTAR PUSTAKA}

1. Febria KD, Sylvia M, Kristiani S. Hubungan lebar mesio distal gigi insisif dengan lengkung geligi pada kasus berdesakan anterior. Jurnal Persatuan Dokter Gigi Indonesia 2007; 2 (57): 52-5.

2. Arthadini DV, Anggani SH. Perubahan lengkung gigi di dalam perawatan ortodonti. Majalah Ilmiah Kedokteran Gigi. 2008; 23 (4): 199-204.

3. Widyanto RM, Puspasari S. Piranti lunak untuk analisis bentuk lengkung gigi dengan jaringan saraf tiruan. J Informatika 2008; 1(9): 8-14.

4. Chandha MH, Zahbia ZN. Pengaruh bentuk gigi geligi terhadap terjadinya impaksi gigi molar ketiga rahang bawah. J Dentofasial 2007; 6(2):65-71. 